\title{
Frequently Abbreviated Works
}

$A A A G$

Annals of the Association of American

Geographers

A.

Arrian, Anabasis

Arch. Mitt. Iran

Archaeologische Mitteilungen aus Iran

Army Veterinary

Army Veterinary Department, Great Britain, Dept. Animal Management (London 1908)

C.

Quintus Curtius, History of Alexander the Great

Clark and Haswell Colin Clark and Margaret Haswell, The Economics of Subsistence Agriculture (London 1970)

D. Diodorus Siculus, Library of History, Book 17

EW

East and West

Geo. Journ.

Geographical Journal

Geo. Rev.

Geographical Review

GGM

Karl Muller, Geographi Graeci Minores (Paris 1855)

Green Peter Green, Alexander of Macedon

(Harmondsworth 1974)

$\mathrm{J}$.

Justin, Epitome

$J R A S$

Journal of the Royal Asiatic Society

JRGS

Journal of the Royal Geographical Society

Maurice

F. Maurice, "The Size of the Army of Xerxes in the Invasion of Greece 480 в.c.," JHS 50 (1930) 210-235 
xiv / Frequently Abbreviated Works

MDAFA Mémoires de la Délégation Archéologique Français en Afghanistan

P. Plutarch, Life of Alexander

Pett. Mitt. Pettermanns Geographische Mitteilungen

PRGS Proceedings of the Royal Geographical Society 